\title{
PENETAPAN BATAS LAUT TERITORIAL INDONESIA- TIMOR LESTE DI WILAYAH LAUT TUMPANG TINDIH
}

\author{
YANTO M.P. EKON \\ Fakultas Hukum Universitas Kristen Artha Wacana \\ Jln. Adisucipto Oesapa Kota Kupang Propinsi Nusa Tenggara Timur \\ Email: ekonyanto@gmail.com
}

\begin{abstract}
Indonesia and Timor Leste in determining the overlapping territorial sea boundaries in the Ombai Strait, Wetar Strait and Timor Sea are increasingly complex and complicated because of the different baseline application rights between the two countries. The difference is that Indonesia as an archipelagic states has the right to apply normal baselines, straight baselines from point to point and straight baselines of islands, while Timor Leste as a coastal state has no right to apply archipelagic baselines but can only apply normal baselines and straight baselines. This paper aims to analyze and explain how to define the territorial sea boundaries etween Indonesia and Timor Leste in the Ombai Strait, Wetar Strait and Timor Sea. This type of research is normative research with data sourced from secondary data. Based on the data and analysis conducted, it can be concluded that the determination of territorial sea boundaries in the Ombai Strait, Wetar Strait and Timor Sea begins with the determination of the base point, drawing baselines and boundary lines by the Indonesia and Timor Leste. However, the obstacle that will be faced by Indonesia and Timor Leste is the existence of islands in overlapping areas, which must first be determined whether or not it can be determined as the base point for drawing the baseline.
\end{abstract}

Key words: states borders, territorial sea, baselines

\begin{abstract}
Abstrak
Indonesia dan Timor Leste dalam menetapkan batas laut teritorial yang tumpang tindih di Selat Ombai, Selat Wetar dan Laut Timor semakin kompleks dan rumit karena hak penerapan garis pangkal yang berbeda antara kedua negara. Perbedaannya adalah Indonesia sebagai negara kepulauan berhak menerapkan garis pangkal normal, garis pangkal lurus dari ujung ke ujung dan garis pangkal lurus kepulauan, sedangkan Timor Leste sebagai negara pantai tidak berhak menerapkan garis pangkal kepulauan melainkan hanya dapat menerapkan garis pangkal normal dan garis pangkal lurus. Tulisan ini bertujuan untuk menganalisis dan menjelaskan cara penetapan batas laut teritorial antara Indonesia dan Timor Leste di Selat Ombai, Selat Wetar dan Laut Timor. Jenis penelitian yang digunakan adalah penelitian normatif dengan data yang bersumber dari data sekunder. Berdasarkan data dan analisis yang dilakukan dapat disimpulkan bahwa penetapan batas laut teritorial di Selat Ombai, Selat Wetar dan Laut Timor diawali dengan penetapan titik dasar, penarikan garis pangkal dan garis batas oleh Indonesia dan Timor Leste. Namun hambatan yang akan dihadapi oleh Indonesia dan Timor Leste adalah keberadaan pulau di wilayah tumpang tindih, yang harus ditentukan terlebih dahulu dapat atau tidaknya ditetapkan sebagai titik dasar penarikan garis pangkal.
\end{abstract}

Kata kunci: batas negara, laut teritorial, garis pangkal 


\section{Latar Belakang}

Laut merupakan salah satu bagian dari wilayah negara, sedangkan wilayah negara merupakan salah satu unsur fundamental dalam hukum internasional untuk membuktikan adanya kedaulatan dan yurisdiksi eksklusif yang dimiliki oleh suatu negara. Hal ini dibenarkan oleh Oppenheim dengan menyatakan "State territory is that definite portion of the surface of the globe which is subjected to the sovereignty of the State. A State without a territory is not possible, although the necessary territory may be very small....". ${ }^{1}$ Demikian pula Malcolm

N. Shaw menyatakan "but sovereignty itself, with its retinue of legal rights and duties, its founded upon the fact of territory. Without territory a legal person cannot be a state". ${ }^{2}$ Menurut kedua ahli hukum internasional tersebut bahwa wilayah negara merupakan bagian dari permukaan bumi sebagai tempat dilaksanakannya kedaulatan negara dan tanpa wilayah maka suatu entitas tidak dapat disebut negara.

Fungsi penting wilayah laut bagi suatu negara antara lain sebagai media komunikasi dan gudang besar sumber daya alam, baik hayati maupun non hayati. ${ }^{3}$ Pentingnya fungsi laut bagi negara, menimbulkan kewajiban hukum bagi setiap negara yang berbatasan untuk menetapkan batas wilayah laut secara jelas berdasarkan prinsip-prinsip dan metode penetapan batas yang ditetapkan dalam hukum laut internasional. Wilayah laut yang perlu ditetapkan batasnya menurut hukum laut internasional adalah wilayah laut antara dua atau lebih negara yang pantainya saling berhadapan atau berdampingan dan terdapat tumpang tindih antara kedaulatan atau yurisdiksi negara yang satu dengan negara yang lain. ${ }^{4}$

Secara teknis, penetapan batas wilayah laut antara negara-negara yang pantainya saling berhadapan atau berdampingan dan tumpang tindih tersebut, dilakukan dengan cara penarikan garis batas untuk memisahkan kedaulatan atau yurisdiksi antara negara yang satu dengan negara yang lain. Oleh karena itu, wilayah laut yang wajib ditetapkan batasnya menurut hukum internasional adalah laut teritorial yang tunduk di bawah kedaulatan negara dan zona ekonomi eksklusif dan landas kontinen yang tunduk di bawah yurisdiksi negara, letak wilayah laut itu di antara dua atau lebih negara yang pantainya saling berhadapan atau berdampingan dan terjadinya tumpang tindih kedaulatan atau yurisdiksi dari dua atau lebih negara atas wilayah laut tersebut karena lebarnya kurang dari 24 (dua puluh empat) mil laut bagi laut teritorial dan

1 Oppenheim, International Law, A Treatise, Vol.I, (London-New York-Toronto:Longmans, Green And Co, 1948), hlm. 407.

2 Malcolm N. Shaw, International Law, (Camridege: University Press, 2008), hlm. 331.

3 Ibid., hlm. 390.

4 Tara Devenport, Southeast Asian Approaches To Maritime Delimitation, (Paper Presented $3^{\text {rd }}$ NUS ASIANSIL Young Scholars Workshop, National University of Singapore: Research Associate, Centre for International Law, 23-24 Februari 2012), hlm. 1. 
200 (dua ratus) mil laut bagi zona ekonomi eksklusif dan landas kontinen. ${ }^{5}$

Wilayah laut teritorial antara Indonesia dan Timor Leste yang termasuk wilayah tumpang tindih dan wajib ditetapkan batasnya menurut hukum laut Internasional adalah wilayah laut di Selat Ombai, Selat Wetar dan Laut Timor. ${ }^{6}$ Tumpang tindih kedaulatan Indonesia dan Timor Leste atas laut teritorial di ketiga wilayah laut ini terjadi setelah Timor Leste menjadi negara merdeka dan berdaulat pada tanggal 20 Mei 2002 dan menuntut kedaulatan dan yurisdiksi atas wilayah laut. Namun Indonesia yang berstatus sebagai negara kepulauan sedangkan Timor Leste sebagai negara pantai, dapat mengakibatkan penetapan batas laut teritorial antara kedua negara menjadi kompleks dan rumit. Kompleks dan rumitnya penetapan batas laut teritorial disebabkan oleh hak penerapan garis pangkal yang berbeda yakni Indonesia sebagai negara kepulauan berhak menerapkan garis pangkal normal, garis pangkal lurus dari ujung ke ujung dan garis pangkal lurus kepulauan, sedangkan Timor Leste sebagai negara pantai tidak berhak menerapkan garis pangkal kepulauan melainkan hanya dapat menerapkan garis pangkal normal dan garis pangkal lurus. ${ }^{7}$ Oleh karena itu, permasalahan yang ingin dibahas dalam tulisan ini adalah bagaimanakah cara penetapan batas laut teritorial antara Indonesia dan Timor Leste di Selat Ombai, Selat Wetar dan Laut Timor?

Jenis penelitian yang digunakan untuk menjawab permasalahan tersebut adalah jenis penelitian normatif, yakni penelitian yang dilakukan melalui studi pustaka atau library research yang diperoleh dari data sekunder. Sumber data sekunder terdiri dari bahan hukum primer, sekunder dan tertier. Bahan hukum primer yaitu bahanbahan hukum yang mengikat, berupa peraturan perundang-undangan, perjanjian internasional dan yurisprudensi, sedangkan bahan hukum sekunder yaitu bahan hukum yang memberikan penjelasan kepada bahan hukum primer, berupa buku, karya ilmiah, artikel-artikel dan doktrin yang berkaitan dengan penetapan batas laut teritorial antara Indonesia dan Timor Leste. ${ }^{8}$ Data yang dikumpulkan dari bahan hukum primer dan bahan hukum sekunder, selanjutnya dianalisis secara kualitatif untuk memperoleh jawaban terhadap cara penetapan batas laut teritorial antara Indonesia dan Timor Leste di Selat Ombai, Selat Wetar dan Laut Timor.

5 Lihat Yoshifuni Tanaka, Predictability and Flexibility in the Law of Maritime Delimitation, (North America (USA and Canada): Oxford and Portland, Oregon, 2006), hlm. 7-8.

6 I. Made Andi Arsana, Chris Rizos \& Clive Schofield, The Application of GIS In Matime Boundary Delimitation, A Case Study on the Indonesia-East Timor Maritime Boundary Delimitation, Australia: University of Wollongong Research Online, 2006), hlm. 2.

7 Lihat hak penggunaan garis pangkal oleh Indonesia sebagai negara kepulauan pada Etty R. Agoes, "Praktek Negara-Negara Atas Konsepsi Negara Kepulauan", Jurnal Hukum Internasional, Vol. 1, No. 3, (April 2004): 457-458. Lihat juga Arie Afrianyah, "Kewenangan Negara Pantai Dalam Mengelola Wilayah Laut", Jurnal Hukum dan Pembangunan, Vol. 45, No. 4 (Oktober-Desember 2015): 611-612.

8 Soerjono Soekanto dan Sri Mamuji, NormatifPenelitian Hukum, Suatu Tinjauan Singkat, (Jakarta: RajaGrafindo, 2003), hlm. 13. 


\section{Pembahasan}

\section{A. Penetapan Batas Laut Teritorial RI-Timor Leste di Selat Ombai (Ombai Strait)}

Selat Ombai terletak di sebelah utara Oecusse yang memisahkan Oecusse di sebelah Barat Timor Leste dengan Pulau Alor dan Pantar yang merupakan wilayah Propinsi Nusa Tenggara Timur, Indonesia, sedangkan secara astronomis terletak pada $8.4^{\circ} \mathrm{S}$ LU dan $8.7^{\circ}$ S LS. ${ }^{9}$ Selat ini termasuk Alur Laut Kepulauan Indonesia (ALKI) III-D dan III-E yang menghubungkan Samudera India dengan Laut Sawu, Laut Banda, Laut Seram, Laut Maluku dan Samudera Pasifik. ${ }^{10}$
Wilayah laut Selat Ombai yang wajib ditetapkan batasnya adalah perairan laut yang terletak di antara Pulau Timor (Oecusse,Timor Leste dan Timor, Indonesia) dengan Pulau Alor, Indonesia yaitu pada perairan bagian timur dan barat. Perairan bagian timur Selat Ombai yaitu perairan di sebelah timur Pulau Alor, bagian barat Pulau Wetar dan Liran, Indonesia dengan Atauro dan Mainland Timor Leste, sedangkan perairan bagian barat adalah Laut Sawu yang terletak di sebelah Barat Oecusse antara Pulau Timor dengan Pulau Pantar dan Alor RI. ${ }^{12}$

Hasil penelitian dari Tim Peneliti Bersama Departemen Teknik Geodesi, Institut Teknologi Bandung, Pusat Pemetaan Batas

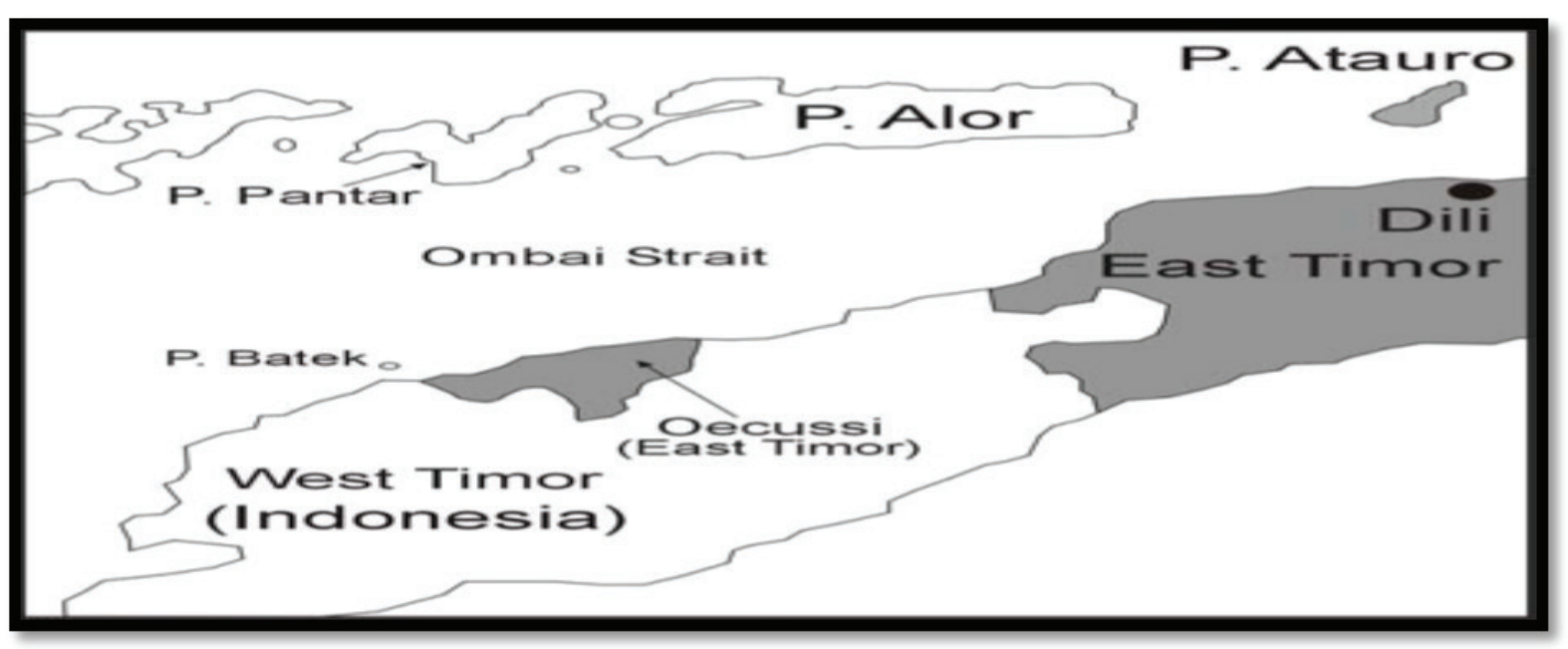

Gambar 1. Wilayah Selat Ombai (Ombai Strait) ${ }^{11}$

9 Lihat James T. Potemra, et., al, Interaction Between the Indonesia and the Indian Ocean in Observations and Numerical Models", Jurnal of Physical Oceanography, Vol. 32 (Juni 2002): 1845.

10 Lihat Mohd Hazmi bin Mohd Rusli, Maritime Highways of Southeast Asia, Alternative Straits?, (Nanyang: S. Rajaratnam School of International Studies, A Graduate School of Nanyang Technological University, 2012, No.024/2012), www.rsis.edu.sg, diakses pada tanggal 15 Maret 2017. Lihat juga Lukman Yudho Prakoso, et.,al, "Sea Defence Strategy and Urgency of Forming Maritime Command Centre" Jurnal Pertahanan, Vol.6, No. 2 (2020):201. Lihat juga Semmy Tyar Armandha, "Posisi Bebas Aktif Indonesia Salam Rivalitas Tiongkok dan Amerika Di Asia Tenggara Terkait Alutsista”, Jurnal Pertahanan, Vol. 6, No. 3, (Desember 2016):120.

11 I. Made Andi Arsana, Chris Rizos \& Clive Schofield, op.cit., hlm.8.

12 Lihat Gambar 1. 
Wilayah dan Pemetaan Dasar Kelautan dan Kedirgantaraan Bakorsutanal serta Puslitbang Geologi Kelautan, Dept ESDM, Bandung menyatakan bahwa jarak dari pantai Pulau Timor (Oecusse, Timor Leste dan Timor, Indonesia) ke pantai Pulau Alor kurang dari 47 mil laut. ${ }^{13}$ Jarak yang kurang dari 47 mil laut itu, setelah dikurangi perairan pedalaman di Pulau Timor dan Alor, maka menurut Dishidros Angkatan Laut Republik Indonesia, Selat Ombai memiliki lebar 16 mil laut dan memiliki kedalaman yang sangat baik untuk pelayaran. ${ }^{14}$ Namun dengan lebar yang hanya 16 mil laut, mengakibatkan terjadi tumpang tindih antara laut teritorial Indonesia dan Timor Leste sehingga perlu ditetapkan batasnya oleh kedua negara.

Prosedur penetapan batas laut teritorial antara Indonesia dan Timor Leste di Selat Ombai memiliki kesamaan dengan penetapan batas laut antar negara pada umumnya, yakni diawali dengan penentuan letak titik dasar dan garis pangkal yang akan diterapkan. Titik Dasar yang perlu ditetapkan sebagai dasar penetapan batas laut teritorial antara Indonesia dan Timor Leste di Selat Ombai adalah titik dasar di Pantai Pulau Timor dan Pulau Alor. Titik dasar yang ditetapkan di Pantai Pulau Timor harus berupa titik dasar bersama antara Indonesia dan Timor Leste sebab letak geografis pantai kedua negara di Pulau Timor saling berdampingan, sehingga dibutuhkan titik dasar bersama untuk menarik garis lateral atau garis sama jarak, guna membatasi wilayah laut kedua negara di bagian barat dan timur Selat Ombai.

Titik dasar bersama yang perlu ditetapkan oleh Indonesia dan Timor Leste di Pulau Timor sebagai dasar penarikan garis pangkal dan garis batas terletak di titik batas darat antara Indonesia dan Timor Leste, sebanyak 3 (tiga) titik dasar bersama, yakni: ${ }^{15}$

1. Titik Dasar Bersama (Cammon Basepints/CD) di Noelbesi, sebagai titik batas darat sebelah barat antara Oecusse, Timor Leste dengan Timor, Indonesia yang secara astronomis terletak pada posisi $09^{0} 10^{\prime} 27.1^{\prime \prime}$ LS dan $124^{\circ} 28^{\prime}$ 33.2" BT, sedangkan secara geografis terletak di sekitar muara sungai Noelbesi. Titik Dasar Bersama ini, berfungsi untuk penarikan garis pangkal dan garis batas yang memisahkan laut teritorial Indonesia di bagian barat Selat Ombai dengan laut teritorial Timor Leste yang terletak di sebelah utara Pantai Oecusse, Timor Leste.

2. Titik Dasar Bersama Noelmeto, sebagai titik batas darat antara Indonesia dan Timor Leste di sebelah timur antara Oecusse, Timor Leste dengan Timor, Indonesia yang secara astronomis

\footnotetext{
13 Hasanuddin Z. Abidin, et al., "Status dan Permasalahan Teknis Dari Delimitasi Batas Laut Indonesia-Timor Leste", Jurnal Suveying dan Geodesi, Vol. XIII No. 1, (Januari 2003):31.

14 Kresno Buntoro, Nusantara dan Alur Laut Kepulauan Indonesia (ALKI), (Jakarta: PT. Raja Grafindo Persada, 2017), hlm. 14.

15 Lihat Hasanuddin Z. Abidin, et al., op.cit., hlm. 35-43.
} 


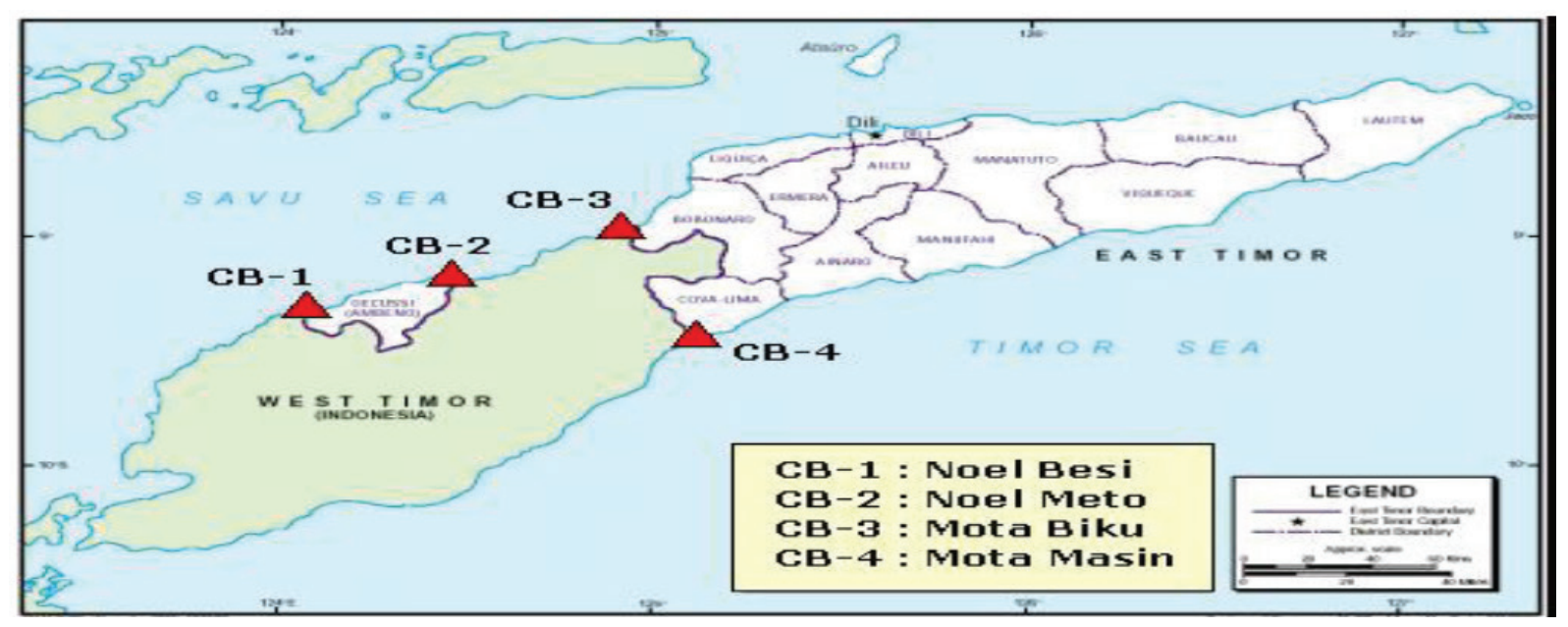

Gambar 2. Titik Batas Bersama Indonesia-Timor Leste ${ }^{16}$

terletak pada posisi $09^{\circ} 20^{\prime} 09.7^{\prime \prime}$ LS dan $124^{\circ} 02^{\prime} 39.1^{\prime \prime}$ BT. Titik batas bersama ini berfungsi sebagai titik dasar penarikan garis pangkal dan garis batas yang memisahkan laut teritorial kedua negara di Selat Ombai, yakni wilayah laut Indonesia yang terletak di antara Batu Gede, Bobonaro, Timor Leste di sebelah timur dengan Oecusse, Timor Leste di sebelah barat.

3. Titik Dasar Bersama Mota Biku, sebagai titik batas darat antara Indonesia dan Timor Leste di sektor timur bagian utara yang memisahkan Timor Barat, Indonesia dengan Timor-Timur, Timor Leste, yang secara astronomis terletak pada posisi $8^{0}$ 57' 23,1" S dan $124^{0} 56^{\prime}$ 57,4" T. Titik batas bersama ini berfungsi sebagai titik dasar penarikan garis pangkal dan garis batas yang memisahkan laut teritorial
Indonesia dan Timor Leste baik di Selat Ombai maupun Selat Wetar.

Sebaliknya titik dasar di sebelah utara Pulau Timor sebagai dasar penentuan lebar laut teritorial dan batas laut di Selat Ombai, telah ditetapkan oleh Pemerintah Republik Indonesia sebanyak 3 (tiga) titik dasar di Pulau Alor, yakni: ${ }^{17}$

1. Titik Dasar No. 112 terletak di Tanjung Lisoma, Pulau Alor dan secara astronomis terletak pada posisi $08^{0} 19^{\prime} 04^{\prime \prime} \mathrm{S}-125^{\circ}$ 08 ' $25^{\prime \prime} \mathrm{T}$. Titik Dasar ini merupakan titik dasar penarikan garis batas sama jarak, yang akan dihubungkan dengan Titik Dasar Bersama Noelmeto di titik batas sebelah timur Oecusse.

2. Titik Dasar No. 113A terletak di Tanjung Seromu, Pulau Alor dan secara astronomis berada pada posisi $08^{0} 21^{\prime} 26^{\prime \prime} \mathrm{S}-125^{\circ}$ 03' 37' T. Titik Dasar ini merupakan titik

16 Titik Batas Bersama ke-4 pada gambar tersebut merupakan titik dasar bersama yang akan difungsikan untuk penentuan lebar laut territorial dan batas laut antara Indonesia dan Timor Leste di Laut Timor. Gambar tersebut dikutip dari Hasanuddin Z. Abidin, et al., Ibid., hlm. 35.

17 Lihat Lampiran Peraturan Pemerintah Nomor: 37 Tahun 2008 Tentang Perubahan Atas Peraturan Pemerintah Nomor: 37 Tahun 2002 Tentang Hak dan Kewajiban Kapal dan Pesawat Udara Asing Dalam Melaksanakan Hak Lintas Alur Laut Kepulauan Yang Ditetapkan. 
dasar penarikan garis batas sama jarak, yang akan dihubungkan dengan Titik Dasar Bersama Motabiku di titik batas darat sektor timur sebelah utara antara Indonesia dan Timor Leste.

3. Titik Dasar No. 113B terletak di Tanjung Siberu, Pulau Alor dan secara astronomis terletak pada posisi $08^{0} 23^{\prime} 58^{\prime \prime} \mathrm{S}-124^{0}$ 47' 10" T. Titik Dasar ini menjadi titik dasar penarikan garis sama jarak, yang akan dihubungkan dengan Titik Dasar Bersama Noelbesi di titik batas darat sebelah barat Oecusse.

Garis pangkal yang dapat diterapkan oleh Timor Leste untuk mengukur lebar laut teritorial atau menetapkan batas lautnya dengan Indonesia di Selat Ombai, adalah garis pangkal normal berdasarkan 2 (dua) alasan. Pertama; Timor Leste merupakan negara pantai yang menurut the 1982 United Nation Convention on the Law of the Sea (UNCLOS) hanya memiliki hak untuk menerapkan garis pangkal normal dan garis pangkal lurus dan kedua; Timor Leste tidak dapat menerapkan garis pangkal lurus untuk menentukan lebar laut teritorial dan batas lautnya dengan Indonesia di Selat Ombai sebab tidak terdapat pulau atau teluk milik Timor Leste yang berada di depan pantai Oecusse sebagai alasan untuk menerapkan garis pangkal lurus. Bahkan Section 1 huruf d Undang-Undang Republik Timor Leste Nomor: 7 Tahun 2002
Tentang Batas Laut Republik Demokratik Timor Leste menetapkan wilayah Timor Leste hanya terdiri dari 4 (empat) pulau yaitu Timor Timur, enclave Oecusse-Ambenu, Atauro dan Jaco.

Berbeda dengan Republik Indonesia, dalam menentukan lebar laut teritorial dan batas laut di Selat Ombai dapat menerapkan garis pangkal lurus kepulauan dan garis pangkal normal. Garis pangkal lurus kepulauan untuk menentukan lebar laut teritorial dan batas laut di Selat Ombai dapat diterapkan oleh Republik Indonesia di 2 (dua) area, yaitu pada Titik Dasar No. 113B di Tanjung Siberu, Pulau Alor ke Titik Dasar Bersama Noelbesi, selanjutnya dihubungkan dengan Pulau Batek dan Pantar serta Titik Dasar No. 113A di Tanjung Seromo, Pulau Alor ke Titik Dasar Bersama Mota Biku dihubungkan dengan Tutun Eden di Pulau Wetar sampai dengan Titik Dasar No. 109 di Pulau Meatiamirang. ${ }^{18}$ Sebaliknya penarikan garis pangkal normal yang diterapkan oleh Republik Indonesia untuk menentukan lebar laut teritorial batas laut dengan Timor Leste di Selat Ombai dimulai dari Titik Dasar No. 113 ke Titik Dasar Bersama Noelmeto. Akibatnya wilayah laut yang berada di antara garis sama jarak dari Titik Dasar No.113-B ke Titik Dasar Bersama Noelbesi dengan Titik Dasar No.113 ke Titik Dasar Bersama Noelmeto menjadi laut teritorial yang dibagi berdasarkan garis tengah antara Indonesia dan Timor Leste. ${ }^{19}$

18 Pandangan ini didasarkan atas gambar 2 dihubungkan dengan Titik Dasar yang ditetapkan dalam Peraturan Pemerintah Nomor: 37 Tahun 2008 Perubahan Atas Peraturan Pemerintah Nomor: 37 Tahun 2002 Tentang Hak dan Kewajiban Kapal dan Pesawat Udara Asing Dalam Melaksanakan Hak Lintas Alur Laut Kepulauan Yang Ditetapkan.

19 Ibid. 
Metode penarikan garis batas yang diterapkan oleh Indonesia dan Timor Leste, mengingat letak dari pantai Alor dan Timor yang dipisahkan oleh Selat Ombai ada yang berdampingan dan berhadapan, maka sesuai dengan Article 12 the 1958 Convention on the Teritorial Sea dan Article 15 the 1982 UNCLOS, metode penarikan garis batas yang tepat untuk diterapkan adalah garis tengah (median line) dan garis sama jarak (equidistance line). Metode garis tengah (median line) diterapkan untuk memisahkan laut teritorial antara Indonesia dan Timor Leste yang berada di antara Pulau Pantar dan Alor dengan Oecusse, sedangkan garis sama jarak (equidistance line) diterapkan untuk membatasi laut teritorial Indonesia dan Timor Leste yang saling berdampingan di Pulau Timor. Berdasarkan garis pangkal dan metode penarikan garis batas, dihubungkan dengan Selat Ombai yang memiliki lebar 16 mil laut, maka lebar laut teritorial dari Republik Indonesia dan Republik Timor Leste di Selat Ombai masing-masing tidak melebihi 8 (delapan) mil laut.
Akan tetapi terdapat 2 (dua) faktor yang akan berpotensi menghambat penetapan batas laut teritorial antara Indonesia dan Timor Leste di Selat Ombai, yaitu titik batas di NoelbesiNoelmeto dan keberadaan Pulau Batek. Titik batas Noelbesi-Noelmeto dapat menjadi hambatan penetapan batas laut teritorial antara Indonesia dan Timor Leste di Selat Ombai karena titik batas tersebut merupakan titik batas darat antara Indonesia dan Timor Leste yang belum disepakati, padahal penetapan batas laut hanya dapat dilakukan jika batas darat telah disepakati dan ditetapkan. ${ }^{20}$ Demikian pula keberadaan Pulau Batek yang terletak di perbatasan antara Kabupaten Kupang dan Oecusse, berpotensi ditolak oleh Timor Leste sebagai pulau yang diberikan bobot penuh untuk memiliki laut teritorial sebab ukurannya sangat kecil, yakni $0,1 \mathrm{~km}$ dan tidak berpenghuni, kecuali telah dibangun menara suar dengan karakter C6s100m20M dan 2 (dua) unit rumah sebagai tempat tinggal penjaga mercusuar oleh Indonesia. ${ }^{21}$

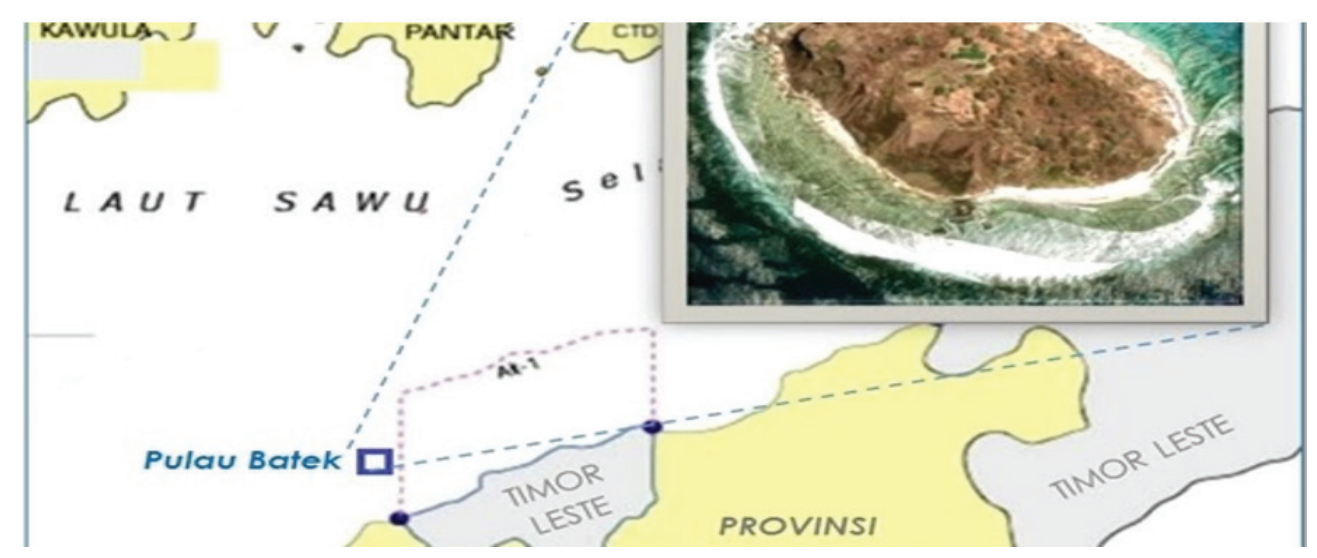

Gambar 3 Ukuran Pulau Batek dan Letaknya Dalam Peta Batas Indonesia-Timor Leste ${ }^{22}$

20 Lihat Mutti Anggita, "Kesepakatan Batas Darat RI-Timor Leste, Sebuah Kajian Diplomasi Perbatasan RI", Jurnal Penelitian Politik, Vol. 11 No. 1, (Juni 2014):24.

21 Pulau Batek, www.ppk-kp3k.kkp.go.id, diakses pada tanggal 07 April 2017.

$22 \mathrm{Ibid}$. 
Keberadaan Pulau Batek sebagai pulau atau karang harus dibuktikan berdasarkan the 1982UNCLOS. Syarat untuk disebut pulau menurut Article 121 par. (1) the 1982 UNCLOS adalah daratan yang terbentuk secara alamiah yang dikelilingi oleh perairan dan selalu tampak di atas permukaan perairan laut, meskipun laut dalam keadaan pasang. Syarat sebagai pulau menurut Article 121 par. (1) the 1982 UNCLOS tersebut, dipenuhi oleh Pulau Batek karena meskipun ukurannya sangat kecil dan tidak berpenghuni tetapi selalu nampak di atas permukaan air laut pada saat air laut pasang. Oleh karena statusnya sebagai pulau, maka menurut Article 47 the 1982 UNCLOS, Pulau Batek memenuhi syarat sebagai salah satu pulau terluar yang dapat ditetapkan oleh Indonesia sebagai titik penarikan garis pangkal lurus kepulauan dalam mengukur lebar laut teritorial dan menentukan batas laut dengan Timor Leste di Selat Ombai. Namun untuk menentukan dapat atau tidaknya Pulau Batek diberikan bobot penuh yang memiliki laut teritorial dalam penetapan batas laut antara Indonesia dan Timor Leste, harus dianalisis pula menurut the 1982 UNCLOS dan putusan-putusan peradilan internasional tentang sengketa batas wilayah laut.

Article 121 par. (2) dan (3) the 1982 UNCLOS secara tegas menetapkan setiap pulau dapat memiliki laut teritorial, zona tambahan, zona ekonomi eksklusif dan landas kontinen, kecuali batu karang yang tidak dapat mendukung kediaman manusia atau kehidupan ekonomi tersendiri, tidak memiliki zona ekonomi eksklusif dan landas kontinen. ${ }^{23}$ Pulau yang tidak diberikan bobot penuh untuk memiliki wilayah laut, juga dibenarkan oleh Mahkamah Internasional, dalam Qatar vs Bahrain case concerning maritime delimitation and territorial question, tanggal 16 Maret 2001. Kasus ini berawal dari tuntutan Qatar terhadap Bahrain berkaitan dengan sengketa atas Pulau Hawar, Zubarah, Dibal dan Qit'at Jaradah serta batas wilayah laut antara kedua negara. Pulau yang disengketakan terletak di wilayah perbatasan laut dari kedua negara, sehingga kedua negara menuntut agar pulau yang disengketakan ditetapkan berada dalam kedaulatan masingmasing negara dan diberikan bobot penuh sebagai dasar untuk mengklaim wilayah laut. Namun Mahkamah Internasional dalam menjatuhkan putusan terhadap batas wilayah laut tidak memberikan bobot kepada pulaupulau yang disengketakan tersebut. ${ }^{24}$

Demikian pul a Putusan International Tribunal for the Law of the Sea (ITLOS) dalam "Dispute Concerning Delimitation of the Maritime Boundary Between Bangladesh and Myanmar in the Bay of Bengal, 14 March

23 Article 121 Par. (2) dan (3) the 1982 UNCLOS menetapkan "Except as provided for in paragraph 3, the territorial sea, the contiguous zone, the exclusive economic zone and the continental shelf of an island are determined in accordance with the provisions of this Convention applicable to other land territory. Rocks which cannot sustain human habitation or economic life of their own shall have no exclusive economic zone or continental shelf"

24 Lihat Case Concerning Maritime Delimitation And Territorial Question Qatar vs Bahrain, 16 Maret 2001, www.icj-cij.org.case, diakses pada tanggal 20 Agustus 2017. 
2012 "25 yang tidak memberikan bobot kepada

Pulau St. Martin untuk memiliki laut teritorial selebar 12 mil laut, padahal pulau ini memiliki populasi penduduk sekitar 7000 jiwa dan luas sekitar $8 \mathrm{~km}^{2}$. Pokok perselisihan dari kasus ini adalah mengenai bobot dari Pulau St. Martin milik Bangladesh untuk diberikan bobot penuh berupa laut teritorial selebar 12 mil laut. Menurut Myanmar, Pulau St. Martin yang terletak di seberang daratan Myanmar tidak dapat diberikan bobot penuh untuk memiliki laut teritorial selebar 12 mil laut, berdasarkan alasan, sebagai berikut:

1. Pulau St. Martin merupakan pulau yang terpisah dari wilayah geografis Bangladesh dan letaknya di seberang daratan Myanmar bukan Bangladesh;

2. Pemberian bobot penuh bagi Pulau St. Martin untuk memperoleh laut teritorial akan mempengaruhi panjang laut teritorial Myanmar, sehingga akan menghasilkan batas laut teritorial yang tidak adil;

3. Pulau St. Martin tidak dapat dianggap sebagai "pulau pesisir" hanya karena letaknya di depan pantai daratan Myanmar. Myanmar mengakui makna pulau dalam Article 121 the 1982 UNCLOS memiliki wilayah laut tetapi Pulau St. Martin tergolong keadaan khusus yang tidak layak diberikan bobot penuh untuk membatasi laut teritorial.
Sebaliknya Bangladesh berpendapat bahwa Pulau St. Martin layak diberikan bobot penuh dan memiliki wilayah laut teritorial sebagaimana ditetapkan dalam Article 121 the 1982 UNCLOS, berdasarkan alasan sebagai berikut:

1. Myanmar telah lama menerima kenyataan bahwa Pulau St. Martin berhak atas laut teritorial selebar 12 mil laut, sedangkan kasus hukum dan praktek negara yang digunakan oleh Myanmar sebagai dasar untuk menolak memberikan bobot penuh kepada Pulau St. Martin, tidak benar sebab: (i) perselisihan ini mengenai batas laut teritorial bukan mengenai batas zona ekonomi eksklusif dan landas kontinen; (ii) sebagian besar perselisihan batas laut yang dikutip oleh Myanmar secara geografis berbeda dengan kasus ini dan (ii) banyak perjanjian yang dikemukakan oleh Myanmar mencerminkan solusi politik yang dicapai dalam konteks penyelesaian kedaulatan dan masalah lain;

2. Pulau St. Martin harus diberikan bobot penuh karena praktek negara yang relevan dengan batas wilayah laut telah membuktikan pulau yang berdekatan dengan pantai dapat dijadikan titik dasar penarikan garis pangkal laut teritorial dan menurut Article 121 the 1982 UNCLOS, pulau memiliki hak atas laut teritorial,

25 Sengketa hukum ini diringkas dari ITLOS Judgment, 2012, Dispute Concerning Delimitation of the Maritime Boundary Between Bangladesh and Myanmar in the Bay of Bengal, Bangladesh Vs Myanmar No, 16. https:// www.itlos.org/cases/list-of-cases/case-no-16" diakses pada tanggal 17 September 2017. 
zona ekonomi eksklusif dan landas kontinen.

Pandangan Myanmar dan Bangladesh yang bersengketa mengenai eksistensi Pulau St. Martin, ITLOS memberikan 3 (tiga) pertimbangan hukum. Pertama; Pulau St. Martin terletak di depan pantai Myanmar, berdekatan baik dengan daratan Bangladesh maupun Myanmar dan berada di dalam batas laut teritorial 12 mil laut dari Pantai Bangladesh, kedua; sebagian besar sengketa hukum dan praktek negara yang dikemukakan oleh Myanmar bukanlah mengenai sengketa batas laut teritorial tetapi tentang sengketa batas zona ekonomi eksklusif dan landas kontinen sehingga tidak relevan dengan batas laut teritorial dan ketiga; meskipun belum pernah terjadi sebelumnya dalam sengketa hukum tentang pulau-pulau yang diberikan bobot rendah dalam batas laut teritorial, tetapi pulau-pulau yang diberikan bobot rendah umumnya tergolong "fitur maritim yang tidak signifikan", seperti pulau Qit'at Jaradah yang ukurannya sangat kecil, tidak berpenghuni dan tidak ada akitivitas (ICJ Reports Qatar vs Bahrain case, 2001). Akhirnya ITLOS berkesimpulan bahwa benar Pulau St. Martin adalah fitur maritim yang signifikan karena ukuran, populasi, tingkat aktivitas ekonomi dan kegiatan lain di pulau itu, tetapi dalam sengketa ini ITLOS memandang tidak ada alasan kuat untuk membenarkan Pulau St. Martin sebagai keadaan khusus dalam penetapan batas sesuai Article 15 the 1982 UNCLOS dan memberikan pulau itu bobot penuh dalam penetapan batas laut teritorial antara Bangladesh dan Myanmar. Oleh karena itu, ITLOS menetapkan batas laut teritorial antara Bangladesh dan Myanmar dengan menerapkan garis sama jarak dan tidak memberikan bobot penuh kepada Pulau St. Martin di wilayah laut teritorial antara kedua negara yang saling tumpang tindih. Sebaliknya karena Pulau St. Martin termasuk dalam wilayah kedaulatan Bangladesh, maka menurut ITLOS bahwa Bangladesh memiliki kedaulatan atas laut teritorial selebar 12 mil laut di sekitar Pulau St. Martin tetapi di wilayah laut yang tidak lagi tumpang tindih dengan laut teritorial Myanmar.

Berpedoman pada ketentuan Article 121 the 1982 UNCLOS dan dua putusan peradilan internasional yaitu Putusan ICJ dalam Qatar vs Bahrain case, 2001 dan Putusan ITLOS dalam Bangladesh vs Myanmar case, 2012, dapat dipahami bahwa meskipun suatu wilayah daratan memenuhi syarat hukum sebagai pulau, baik yang berpenghuni maupun tidak berpenghuni atau berukuran kecil maupun besar, tidak serta-merta diberikan bobot penuh untuk memiliki wilayah laut. Sehubungan dengan status Pulau Batek, meskipun telah memenuhi syarat sebagai pulau seperti yang ditetapkan dalam Article 121 par. (1) the 1982 UNCLOS tetapi secara geologis bukanlah pulau melainkan tergolong karang dan karena itu masyarakat setempat menyebut pulau ini dengan nama "Fatu Sinai" artinya Batu Sinai serta ukurannya sangat kecil yakni hanya 0,1 $\mathrm{km}$ dan tidak berpenghuni serta tidak terdapat 
aktivitas ekonomi di atasnya. Oleh karena itu, berdasarkan Article 121 par. (2) dan (3) the 1982 UNCLOS dan putusan-putusan peradilan internasional sebagaimana diuraikan di atas, menurut penulis meskipun Indonesia menerapkan garis pangkal lurus kepulauan dengan menghubungkan Pulau Batek, Pantar dan Noelbesi dalam menetapkan batas laut teritorial dengan Timor Leste, tetapi Pulau
Batek tidak dapat diberikan bobot penuh untuk memiliki laut teritorial.

I. Made Andi Arsana, Chris Rizos \& Clive Schofield mengkonstruksikan batas laut teritorial antara Indonesia dan Timor Leste di Selat Ombai dengan membandingkan pemberian bobot penuh, setengah dan nol kepada Pulau Batek, seperti gambar berikut ini.

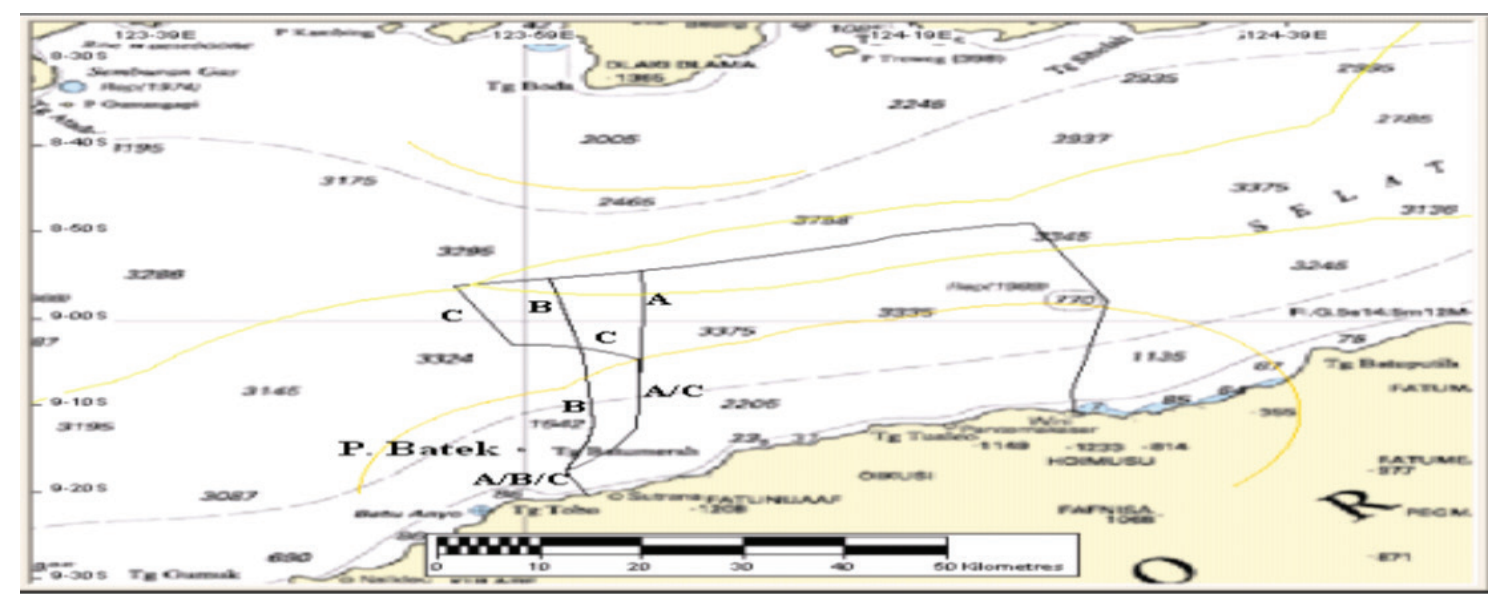

Gambar 4. Peta berbandingan pemberian bobot kepada Pulau Batek ${ }^{26}$

Garis C pada gambar tersebut laut di sebelah timur garis B, tanpa adanya dikonstruksikan dengan memberikan bobot dampak semi-enclave laut teritorial bagi nol atau mengabaikan Pulau Batek dan Pulau Batek. Demi pertimbangan prinsip garis B memberikan bobot setengah kepada keadilan (equity) bagi Indonesia dan Timor Pulau Batek, sedangkan garis A memberikan Leste maka pemberian bobot setengah kepada bobot penuh kepada Pulau Batek. Perbedaan Pulau Batek sebagaimana garis batas B dapat antara garis $\mathrm{C}$ dan $\mathrm{B}$ adalah garis $\mathrm{C}$ yang dipertimbangkan untuk diterapkan oleh kedua memberikan bobot nol kepada Pulau Batek mengakibatkan Pulau Batek memiliki kantong laut teritorial yang berbatasan dengan ZEE Timor Leste di sebelah utara Pulau Batek, sedangkan garis B yang memberikan bobot setengah kepada Pulau Batek mengakibatkan garis batas akan menuju utara beberapa mil negara. ${ }^{27}$

Penulis berpendapat bahwa Pulau Batek tidak perlu diberikan bobot penuh untuk memiliki laut teritorial berdasarkan 3 (tiga) alasan. Pertama; Pulau Batek yang terletak di wilayah perbatasan Indonesia-Timor Leste tergolong fitur maritim yang tidak

26 I. Made Andi Arsana, Chris Rizos \& Clive Schofield, op.cit.,hlm. 10.

27 Ibid., hlm. 11. 
signifikan sebab ukurannya sangat kecil, tidak berpenghuni dan tidak ada aktifitas. Kedua; Pulau Batek dapat dijadikan salah satu titik dasar bagi Republik Indonesia untuk melakukan penarikan garis pangkal lurus kepulauan guna dihubungkan dengan Titik Dasar Bersama Noelbesi, Titik Dasar No. 113 di Pulau Alor dan Pantar, tetapi tidak perlu diberikan bobot penuh untuk memiliki laut teritorial di daerah tumpang tindih sebab letaknya berada di luar garis sama jarak antara Indonesia dan Timor Leste, tepatnya di sebelah barat garis sama jarak. Ketiga; Pulau Batek tidak perlu diberikan bobot penuh untuk memiliki laut teritorial di area tumpang tindih untuk menghindari adanya sengketa batas laut dengan Timor Leste.

\section{B. Penetapan Batas Laut Teritorial RI-Timor Leste di Selat Wetar (Wetar Strait)}

Selat Wetar adalah selat yang memisahkan bagian timur dari Pulau Timor dengan Pulau Wetar. Selat ini berada di antara Pulau Wetar, Propinsi Maluku, Indonesia di sebelah utara dan Dili, Timor Leste di sebelah selatan. Sebaliknya di sebelah baratnya terdapat Pulau Atauro, Timor Leste dan sebelah timur melalui wilayah laut antara Pulau Kisar dan Leti, Indonesia di sebelah utara dan Pulau Jaco, Timor Leste di sebelah selatan. Wilayah ini juga menghubungkan Laut Banda di belahan utara ke Laut Sawu di arah barat daya. ${ }^{28}$

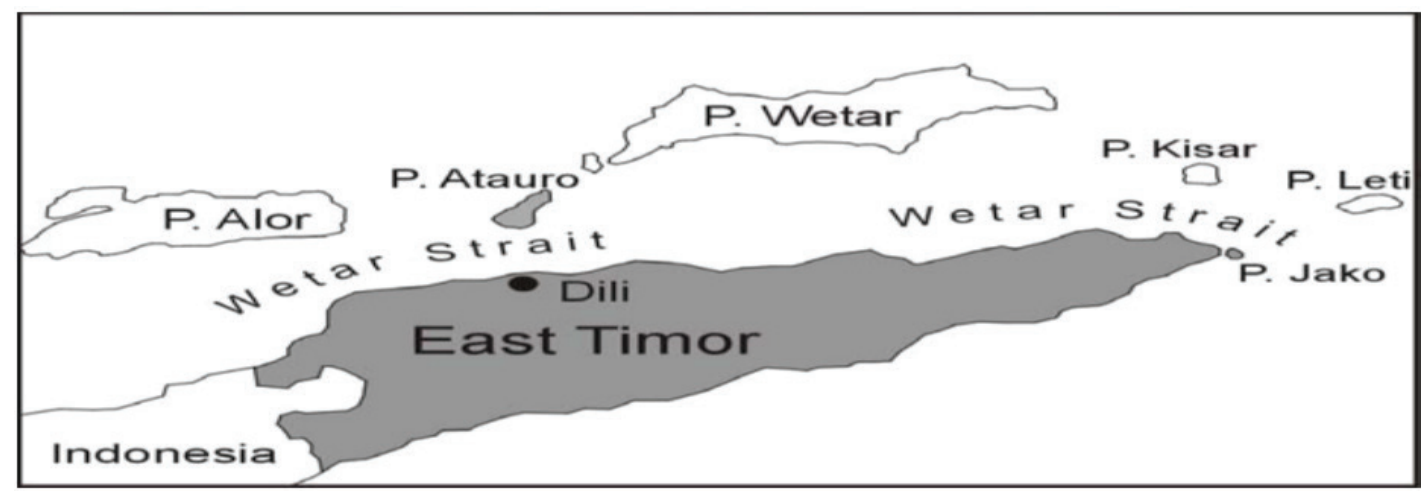

Gambar 5. Wilayah Selat Wetar (Wetar Strait) ${ }^{29}$

Selat Wetar yang perlu ditetapkan batasnya oleh Indonesia dan Timor Leste adalah perairan yang terletak antara Pulau Atauro dan Dili, Timor Leste dengan Pulau Wetar, serta perairan selat antara Pulau Kisar dan Leti, di bagian utara dan Pulau Jaco, Timor Leste di bagian selatan. Hasil penelitian dari Tim
Peneliti Bersama Departemen Teknik Geodesi, Institut Teknologi Bandung, Pusat Pemetaan Batas Wilayah dan Pemetaan Dasar Kelautan dan Kedirgantaraan Bakorsutanal serta Puslitbang Geologi Kelautan, Dept ESDM, Bandung menyatakan bahwa Selat Wetar memiliki lebar 9-34 mil laut. ${ }^{30}$ Sebaliknya

28 Sequito Monteiro, "Yurisdiksi Negara Pantai Di Wilayah Delimitasi Maritim Zona Ekonomi Eksklusif Yang Belum Ditetapkan Berdasarkan Ketentuan Hukum Laut Internasional” Jurnal Komunikasi Hukum (JKH) Universitas Pendidikan Ganesha, Vol. 6, No. 1 (Februari 2020): 306.

29 I. Made Andi Arsana, Cris Rizos \& Clive Schofield, loc.cit.,

30 Hasanuddin Z. Abidin, et al., op.cit., hlm. 31. 
menurut Dishidros Angkatan Laut Republik Indonesia, Selat Wetar memiliki lebar 16 mil laut atau setidaknya kurang dari 24 mil laut dan memiliki kedalaman yang sangat baik untuk pelayaran. Selat Wetar dan Selat Ombai saat ini digunakan untuk lalu lintas perdagangan yang menghubungkan antara Australia, Timor Leste, Laut Jawa dengan Laut Banda, Laut Sulawesi dan Samudera Pasifik. ${ }^{31}$

Indonesia dan Timor Leste dalam menentukan lebar laut teritorial dan menetapkan batas laut di Selat Wetar harus menetapkan 1 (satu) Titik Dasar Bersama di Mota Biku. Mota Biku merupakan titik batas darat antara kedua negara di sektor timur sebelah utara dan letaknya berada pada posisi $8^{0} 57$ ' 93,1" - 1240 56' 57,4" T. ${ }^{32}$ Negara Republik Indonesia dalam menentukan lebar laut teritorial dan batas laut di Selat Wetar telah menetapkan 3 (tiga) titik dasar, yakni:

1. Titik Dasar No. TD. 111 di Tutun Yen, Pulau Kisar dan secara astronomis terletak pada posisi $08^{0} 06^{\prime} 07^{\prime \prime} \mathrm{S}-127^{0}$ 08 ' 52 " T.

2. Titik Dasar No. TD. 112, di Tutun Eden Wetar, Pulau Kisar dan secara astronomis terletak pada posisi $07^{0} 58^{\prime} 31^{\prime \prime} \mathrm{S}-126^{0}$ 27 ' 59" T.
3. Titik Dasar No. 112A, di Pulau Lirang dan secara astronomis terletak pada posisi $08^{0} 03^{\prime} 44^{\prime \prime} \mathrm{S}-125^{\circ} 44^{\prime} 06^{\prime \prime}$ T. ${ }^{33}$

Sebaliknya Timor Leste, sampai sekarang belum menetapkan titik dasar untuk menentukan lebar laut teritorial dan batas laut di Selat Wetar. Namun diperkirakan titik dasar yang akan ditetapkan oleh Timor Leste terletak di pantai sebelah utara Timor-Timur dan Atauro, yakni 7 (tujuh) titik dasar titik dasar di pantai utara Timor-Timur, sedangkan 2 (dua) titik dasar di Pulau Atauro. ${ }^{34}$

Merujuk pada titik-titik dasar yang telah ditetapkan oleh Indonesia dan sesuai dengan Peraturan Pemerintah Nomor: 37 Tahun 2008 Tentang Perubahan Atas Peraturan Pemerintah Nomor: 38 Tahun 2002 Tentang Daftar Koordinat Geografis Titik-Titik Garis Pangkal Kepulauan Indonesia, garis pangkal yang diterapkan oleh Indonesia untuk menentukan lebar laut teritorial dan batas laut dengan Timor Leste di Selat Wetar adalah garis pangkal lurus kepulauan. Garis pangkal lurus kepulauan tersebut akan ditarik dari Titik Dasar Bersama Mota Biku ke Titik Dasar 112A di Pulau Lirang, Titik Dasar 112 di Tutun Eden dan Titik Dasar 111 di Tutun Yen, Pulau Kisar, dihubungkan dengan Titik Dasar 110A

31 Kresno Buntoro, op.cit., hlm. 14. Lihat juga Suharyo, "Penegakan Keamanan Maritim Dalam NKRI dan Problematikanya", Jurnal Penelitian Hukum De Jure, Vol. 19, No. 3, (September 2019):288.

32 Lihat Gambar 2.

33 Lampiran PP No. 37 Tahun 2008 Tentang Perubahan Atas PP No. 38 Tahun 2002 Tentang Daftar Koordinat Geografis Titik-Titik Garis Pangkal Kepulauan Indonesia.

34 Perkiraan letak titik dasar dari Timor Leste didasarkan pada posisi atau letak dari Titik Dasar yang ditetapkan oleh Negara Republik Indonesia di dalam PP No. 37 Tahun 2008 dan hasil penelitian bersama Departemen Teknik Geodesi, Institut Teknologi Bandung, Pusat Pemetaan Batas Wilayah, Bakorsutanal, Pusat Pemetaan Dasar Kelautan dan Kedirgantaraan, Bakorsutanal, dan Puslitbang Geologi Kelautan, Departemen ESDM, Bandung. Lihat Hasanuddin Z. Abibin, op.cit., hlm. 34. 
dan Titik Dasar 110 di Tanjung Kesioh dan Tanjung Karang, Pulau Leti sampai dengan Titik Dasar 109 di Pulau Meatiamiarang.

Berbeda dengan Timor Leste yang karena merupakan negara pantai, maka dalam penentuan lebar laut teritorial dan batas laut di Selat Wetar, Timor Leste dapat menerapkan garis pangkal lurus. Garia pangkal lurus dapat diterapkan oleh Timor Leste dalam penentuan lebar laut teritorial di Selat Wetar sebab terdapat Pulau Atauro di depan pantai TimorTimur. Jarak antara Pulau Atauro dengan Dili, Timor Leste adalah $25 \mathrm{~km}$ atau 2,70 mil laut, karena itu garis pangkal lurus yang dapat diterapkan oleh Timor Leste di Selat Wetar adalah menghubungkan Titik Dasar Bersama di Mota Biku ke Titik Dasar di Pulau Atauro dan ujung timur dari Timor-Timur.

Apabila Timor Leste menerapkan garis pangkal lurus di Selat Wetar untuk menentukan lebar laut teritorial dan batas laut dengan Indonesia maka akan mengakibatkan wilayah laut yang berada di antara Pulau Atauro dan Timor-Timur menjadi laut pedalaman Timor Leste. Namun karena perairan laut di antara Pulau Atauro dengan Timor-Timur tersebut, sebelumnya merupakan jalur pelayaran internasional, maka sesuai Article 8 paragraf (2) the 1982 UNCLOS berlaku hak lintas damai bagi kapal-kapal asing. Selain itu, wilayah laut di Selat Wetar yang menjadi wilayah tumpang tindih dan perlu ditetapkan batasnya oleh Indonesia dan Timor Leste adalah wilayah laut di antara Pulau Atauro, Alor, Liran dan Wetar serta antara Pulau
Wetar, Kisar dan Leti di sebelah utara dengan Timor-Timur dan Jaco di sebelah selatan. Berdasarkan letak geografis antara pulaupulau tersebut yang saling berhadapan maka sesuai dengan Article 12 the 1958 Convention on the Teritorial Sea dan Article 15 the 1982 UNCLOS, metode penarikan garis batas yang diterapkan oleh Indonesia dan Timor Leste dalam penetapan batas laut teritorial adalah garis tengah (median line).

Faktor penting yang patut diperhatikan oleh Indonesia dan Timor Leste dalam penarikan garis pangkal dan garis batas antara lain tentang pemberian bobot kepada Pulau Atauro untuk memiliki laut teritorial. Persoalan diberikan atau tidaknya bobot penuh kepada Pulau Atauro, milik Timor Leste untuk memiliki laut teritorial, dapat dirundingkan oleh kedua negara dengan mendasarkan pada the 1982 UNCLOS dan putusan-putusan peradilan internasional. Berpedoman pada Article 121 par. (2) dan (3) the 1982 UNCLOS, Pulau Atauro milik Timor Leste memiliki hak atas laut teritorial, zona ekonomi eksklusif dan landas kontinen sebab Pulau Atauro yang letaknya sekitar 2,70 mil laut di sebelah utara Dili, Timor Leste dan secara administratif termasuk salah satu subdistrik dari Distrik Dili, tergolong pulau yang memiliki luas $105 \mathrm{~km}^{2}$ dan berpenghuni dengan penduduk sekitar 8000 jiwa. Namun dengan merujuk pada Putusan ITLOS dalam "Dispute Concerning Delimitation of the Maritime Boundary Between Bangladesh and Myanmar in the Bay of Bengal, 14 March 2012" maka 
Pulau Atauro tergolong fitur maritim yang signifikan sebab ukuran, populasi penduduk, tingkat aktivitas ekonomi dan kegiatan lain di pulau itu, tetapi tidak dapat memiliki laut teritorial di wilayah laut teritorial Indonesia dan Timor Leste yang tumpang tindih.

Batas laut teritorial antara Indonesia dan Timor Leste di Selat Ombai dan Selat Wetar telah dirancang oleh Dishidros Angkatan Laut Republik Indonesia pada tahun 2008, setelah diterbitkannya Peraturan Pemerintah Nomor: 37 Tahun 2008 Tentang Perubahan Atas PP No. 38 Tahun 2002 Tentang Daftar Koordinat Geografis Titik-Titik Garis Pangkal Kepulauan Indonesia, seperti gambar berikut ini: ${ }^{35}$

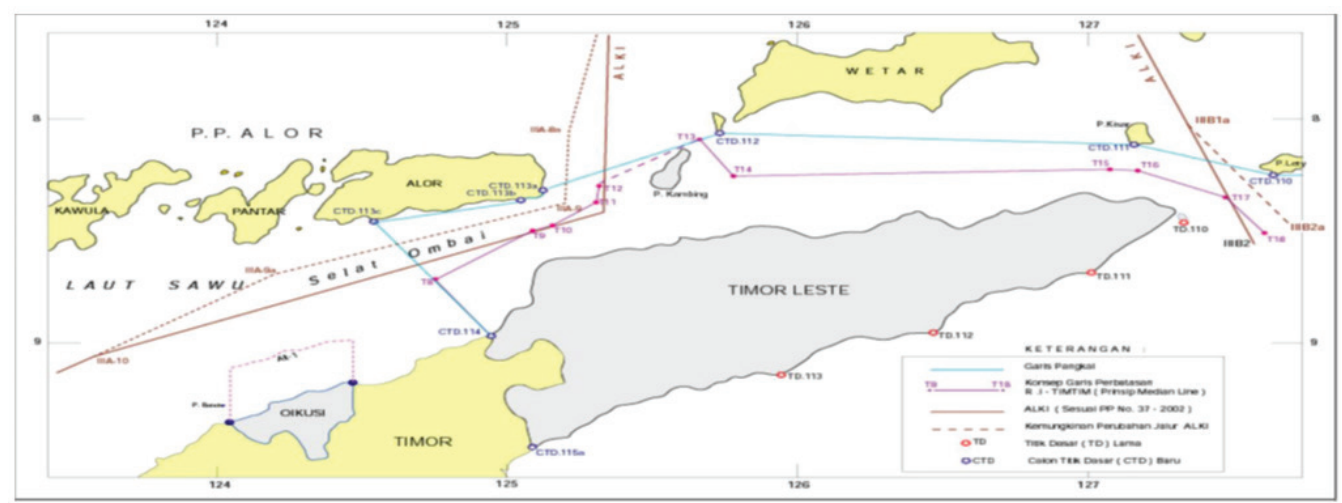

\section{Gambar 6. Batas Laut Teritorial RI-TL di Selat Wetar dan Ombai Rancangan TNI-AL}

Gambar di atas menunjukan bahwa batas laut teritorial antara Indonesia dan Timor Leste di Selat Ombai, kedua negara samasama menerapkan garis pangkal normal dan metode penarikan garis sama jarak (equidistance line) dari Noelbesi, di sebelah barat Oecusse dan Noelmeto di sebelah timur Oecusse, selanjutnya ditutup dengan garis tengah (median line) sebagai garis batas laut teritorial antara Indonesia dan Timor Leste di Selat Ombai. Pulau Batek tidak diberikan bobot untuk memiliki laut teritorial karena tidak dijadikan sebagai titik dasar penarikan garis pangkal. Hal ini berarti Pulau Batek terletak di dalam wilayah laut teritorial Indonesia, yang jika diperbandingkan dengan
Putusan ICJ dalam Bangladesh vs Myanmar case maka sama dengan Pulau St. Martin yang letaknya di dalam laut teritorial Bangladesh tidak diberikan bobot untuk memiliki laut teritorial di wilayah laut yang tumpang tindih.

Sebaliknya penetapan batas laut di Selat Wetar, Indonesia menerapkan garis pangkal lurus kepulauan dengan menghubungkan titik batas darat antara Indonesia dan Timor Leste di Pulau Timor dengan Pulau Alor, Pulau Liran, Pulau Kisar dan Pulau Leti. Akibatnya Titik Dasar (TD) yang menurut Peraturan Pemerintah Nomor: 38 Tahun 2002 Tentang Daftar Koordinat Titik Geografis Garis Pangkal Kepulauan Indonesia menjadi batal demi hukum karena terletak di bagian 
selatan Pantai Timor Leste yang bukan lagi menjadi wilayah kedaulatan Indonesia. Titik dasar yang dipindahkan ke sebelah utara Pantai Timor sebagaimana ditetapkan dalam Peraturan Pemerintah Nomor: 37 Tahun 2008 Tentang Perubahan Atas Peraturan Pemerintah Nomor: 38 Tahun 2002, adalah Titik Dasar 109 sampai dengan Titik Dasar 113B yang ditempatkan di Pulau Meatiamiarang, Leti, Kisar, Wetar, Lirang dan Alor.

Wilayah laut yang terletak di antara Timor-Timur dan Pulau Jaco dengan Pulau Atauro (Kambing) milik Timor Leste menjadi laut pedalaman Timor Leste karena Pulau Atauro akan ditetapkan oleh Timor Leste sebagai titik dasar penarikan garis pangkal. Namun garis pangkal lurus kepulauan yang menghubungkan Tanjung Losomu, Pulau Alor (CTD-113) dengan Tutun Eden, Pulau Wetar berpotensi memotong laut teritorial Timor Leste di sebelah selatan Pulau Atauro. Pemerintah Timor Leste juga telah merancang batas wilayah laut teritorial dengan Indonesia di Selat Ombai dan Selat Wetar dengan membuat peta batas antara kedua negara, seperti gambar berikut ini. ${ }^{36}$

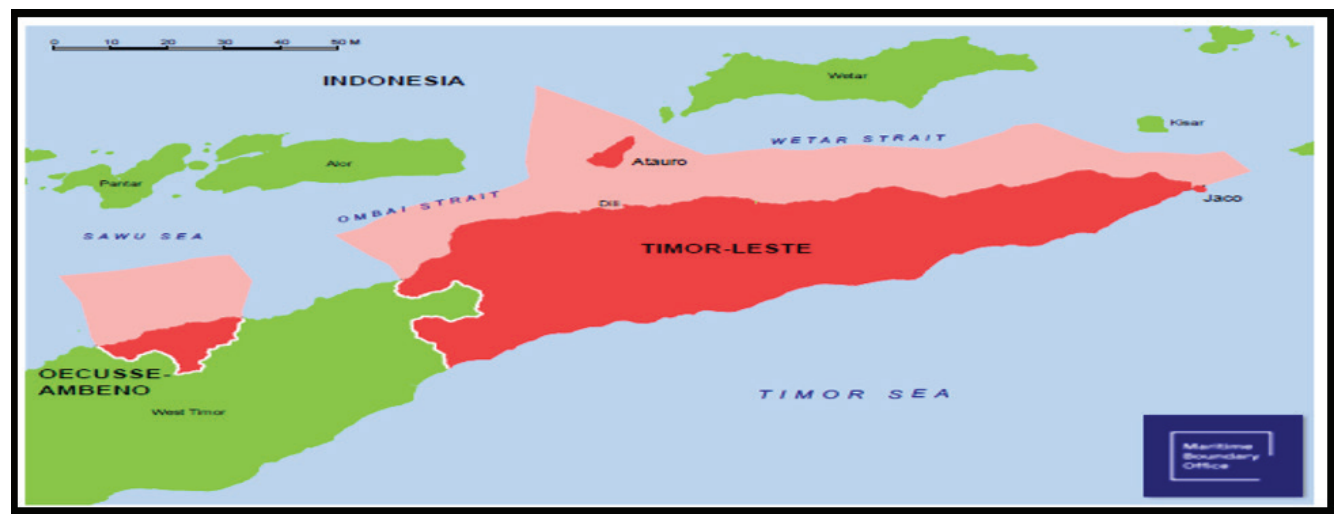

Gambar 7. Batas Laut Teritorial RI-TL Rancangan Timor Leste

Gambar di atas menunjukan bahwa batas laut teritorial antara Indonesia dan Timor Leste di Selat Ombai dan Wetar, yang dirancang oleh Pemerintah Timor Leste tidak memiliki perbedaan yang bersifat mendasar dengan hasil rancangan Dishidros Angkatan Laut Republik Indonesia. Salah satu perbedaan antara batas wilayah laut hasil rancangan Pemerintah Indonesia dengan Timor Leste adalah rancangan batas oleh Pemerintah Indonesia memberikan bobot nol kepada Pulau Atauro, sedangkan hasil rancangan Pemerintah Timor Leste memberikan bobot penuh kepada Pulau Atauro karena memperluas laut teritorialnya ke arah selatan Pulau Atauro dan mencaplok sebagian wilayah laut yang terletak di antara Pulau Alor dan Tutun Eden Pulau Wetar. Perbedaan pandangan antara Indonesia dan Timor Leste di wilayah laut antara Pulau Alor, Tutun Eden, Pulau Wetar berpotensi menimbulkan adanya sengketa batas antara Indonesia dan Timor Leste. 


\section{Penetapan Batas Laut Teritorial RI-Timor Leste di Laut Timor (Timor Sea)}

Laut Timor merupakan perpanjangan dari Samudera Hindia yang terletak di antara Pulau Timor Indonesia dan Timor Leste di sebelah Utara dan Australia di sebelah Selatan, sedangkan di sebelah Timur berbatasan dengan Laut Arafura dan di sebelah Barat dengan ujung tenggara Pulau Rote. Luas wilayah laut ini adalah 300 mil, sedangkan titik terdalam di Palung Timor (Timor Trough) dengan kedalaman 3.300 meter (10.800 kaki) dan bagian lebih dangkal memiliki kedalaman rata-rata kurang dari 200 meter (650 kaki), padahal the 1982 UNCLOS, menetapkan setiap negara dapat mengklaim landas kontinen menjadi yurisdiksi eksklusifnya selebar 200 mil laut. Kemudian ditinjau dari sumber daya alamnya, landas kontinen di Laut Timor kaya akan bahan tambang seperti bebatuan yang mengandung berlian dan cadangan minyak serta gas bumi. ${ }^{37}$ Laut ini merupakan tempat utama munculnya badai tropis dan topan, tetapi kaya akan sumber daya perikanan, sehingga sejak dahulu kala sampai sekarang terdapat banyak nelayan dari Pulau Rote, Flores, Alor, Buton, Sabu, Madura, Timor dan Maluku selalu melaut di wilayah laut ini. ${ }^{38}$

Batas laut teritorial di Laut Timor yang perlu ditetapkan batasnya oleh Indonesia dan
Timor Leste adalah wilayah laut yang terletak di sebelah selatan Pulau Timor. Penetapan batas laut teritorial di wilayah laut ini, Indonesia dan Timor Leste perlu menetapkan 1 (satu) titik dasar bersama di Mota Masin, yang merupakan titik batas darat antara Indonesia dan Timor Leste di sektor timur Pulau Timor sebelah selatan dengan letak posisi pada $8^{0}$ 57' 23,1"S-1240 56' 57,4"T. ${ }^{39}$ Titik Dasar Bersama di Mota Masin berfungsi sebagai titik dasar penarikan garis batas sama jarak ke arah selatan Pulau Timor untuk memisahkan laut teritorial Indonesia dan Timor Leste di sebelah barat.

Sebaliknya titik dasar di sebelah timur akan menjadi rumit dan kompleks karena terdapat pulau Jaco milik Timor Leste dan Leti, Moa serta Lacor, milik Indonesia yang perlu memperoleh pertimbangan khusus. ${ }^{40}$ Pertimbangan khusus yang dimaksudkan adalah dapat atau tidaknya pulau-pulau kecil seperti Jaco, Timor Leste serta Leti, Moa dan Lacor, Indonesia diberikan bobot penuh untuk memiliki laut teritorial. Timor Leste, melalui tulisan dari H.E. Dr. Rui Maria de Araujo dan Kay Rala Xanana Gusmao selaku Kepala Negosiator Dewan Delimitasi Batas Laut Timor Leste, yang dipublikasikan oleh Maritime Boundary Office Timor Leste menolak secara tegas pemberian bobot penuh kepada kumpulan pulau Leti, Moa dan Lacor,

37 Laut Timor, Wikipedia, https://id.wikipedia.org, diakses pada tanggal 4 Maret 2020

38 Japanton Sitohang, et al, Masalah Perbatasan Wilayah Laut Indonesia di Laut Arafura dan Laut Timor, (Jakarta: Lembaga Ilmu Pengetahuan Indonesia, 2009), hlm. 121-122.

39 Lihat Hasanuddin Z. Abibin, et al., hlm. 38.

40 I. Made Andi Arsana, op.cit., hlm. 181-182. 
Indonesia untuk memiliki laut teritorial. Menurut Timor Leste, secara faktual Pulau Leti, Moa dan Lacor tidak dapat diberikan bobot penuh karena tergolong pulau kecil, terpencil, jarang penduduk dan aktivitas ekonomi yang terbatas. Demikian pula secara yuridis, Timor Leste mendasarkan pada putusan Black Sea case antara Rumania vs Ukraina oleh ICJ yang tidak memberikan bobot penuh kepada Pulau Serpen dan Banglades vs Myanmar case oleh ITLOS yang tidak memberikan bobot penuh kepada Pulau St. Martin serta Qatar vs Bahrain case oleh ICJ, yang tidak memberikan bobot penuh kepada pulau-pulau kecil di wilayah perbatasan untuk memiliki laut teritorial. ${ }^{41}$

Penolakan pemberian bobot penuh kepada kumpulan Pulau Leti, Moa dan Lacor oleh Timor Leste didorong oleh keinginan Timor Leste untuk mengklaim ladang minyak Greater Sunrise dari Australia, sebab dengan merujuk pada Perjanjian Batas Dasar Laut antara Indonesia dan Australia, 1972 maka Indonesia berkeinginan untuk memberikan bobot penuh kepada ketiga pulau kecil tersebut. Akibat hukum dari bobot penuh yang diberikan kepada Pulau Leti, Moa dan Lacor untuk memiliki laut teritorial dapat menimbulkan 2 (dua) hal, yakni:

1. Garis sama jarak (equidistance line) yang ditarik di sebelah timur cukup ketat dan berpotensi mempersempit laut teritorial Timor Leste; dan
2. Ladang minyak Greater Sunrise yang diklaim oleh Australia dan Timor Leste berpotensi menjadi landas kontinen Australia, padahal Timor Leste sangat berkepentingan untuk memiliki ladang minyak tersebut. Oleh karena itu, Timor Leste menegaskan bahwa jika Indonesia dalam negosiasi batas wilayah laut tetap berkeinginan memberikan bobot penuh kepada Pulau Leti, Moa dan Lacor, maka Timor Leste lebih memilih penyelesaian batas laut antara Indonesia, Australia dan Timor Leste melalui peradilan internasional karena putusannya tidak memihak melainkan didasarkan pada ketentuan hukum internasional positif yang berlaku. ${ }^{42}$

Rumit dan kompleksnya penarikan garis sama jarak di sebelah timur Pulau Timor untuk membatasi laut teritorial antara Indonesia dan Timor Leste di Laut Timor akan menjadi hambatan tersendiri bagi kedua negara. Hal ini disebabkan penarikan garis batas tersebut hanya dapat terlaksana jika kedua negara telah sepakat mengenai besarnya bobot yang diberikan kepada Pulau Jaco, Timor Leste serta Leti, Moa dan Lacor, Indonesia. Bobot yang diberikan kepada pulau-pulau terluar seperti Jaco, Timor Leste serta Leti, Moa dan Lacor, Indonesia, sebenarnya telah diatur dalam hukum laut internasional modern yang terbentuk melalui putusan-putusan peradilan internasional. Berdasarkan putusan Black Sea

41 Rui Maria de Araujo \& Kay Rala Xanana Gusmau, op.cit., hlm. 64.

42 Ibid., hlm. 65. 
case antara Rumania vs Ukraina oleh ICJ, Banglades vs Myanmar case oleh ITLOS dan Qatar vs Bahrain case oleh ICJ, dapat dipahami bahwa demi penerapan prinsip equity (keadilan) pulau-pulau terluar baik yang berpenghuni atau tidak berpenghuni maupun kecil atau besar tidak diberikan bobot penuh untuk memiliki laut teritorial. Oleh karena itu, Pulau Jaco milik Timor Leste maupun Pulau Leti, Moa dan Lacor milik Indonesia tidak patut diberikan bobot penuh untuk memiliki laut teritorial.

Menurut I. Made Andi Arsana, dalam penarikan garis batas laut teritorial antara Indonesia dan Timor Leste, Pulau Jaco milik Timor Leste dan Leti, Moa dan Lacor milik Indonesia tidak perlu diberikan bobot penuh melainkan Pulau Jaco, milik Timor Leste diberikan bobot nol, Leti milik Indonesia diberikan bobot setengah, sedangkan Moa dan
Lacor juga diberikan bobot nol. Pemberian bobot setengah kepada Pulau Leti disebabkan Pulau Leti secara signifikan lebih besar daripada Pulau Jaco dan memiliki garis pantai yang lebih panjang, sehingga layak diberikan bobot yang lebih besar. Sebaliknya Pulau Moa dan Lacor diberikan bobot nol untuk menghindari terjadinya penyempitan laut teritorial Timor Leste. ${ }^{43}$ Namun rekomendasi tersebut merupakan rekomendasi akademik yang tidak bersifat mengikat, melainkan yang mengikat adalah hasil kesepakatan antara Indonesia dan Timor Leste melalui Tim Perunding kedua negara.

Batas laut teritorial antara Indonesia dan Timor Leste di Laut Timor telah dirancang pula oleh Dishodros Angkatan Laut Republik Indonesia, sebagaimana pada gambar berikut ini.

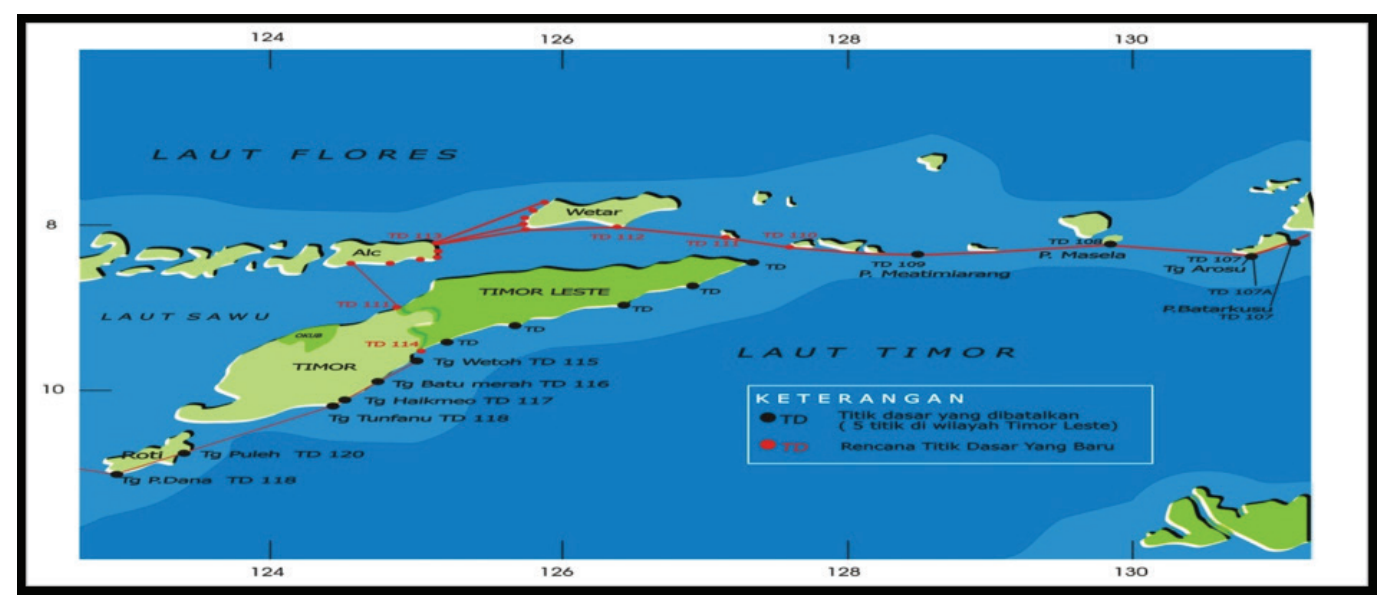

Gambar 8. Rancangan batas Laut Teritorial Indonesia-Timor Leste di Laut Timor ${ }^{44}$

43 I. Made Andi Arsana, op.cit., hlm. 184-185.

44 Dikutip dari Sudjatmiko dan Rusdi Ridwan, "Batas-Batas Maritim antara Republik Indonesia dengan Negara Tetangga", Jurnal Hukum Internasional, Edisi Khusus, Lembaga Pengkajian Hukum Internasional Fakultas Hukum Universitas Indonesia, (Desember 2004):104. 
Gambar di atas menunjukan bahwa Titik Dasar Bersama antara Indonesia dan Timor Leste di Mota Masin diberi nomor TD-114. Titik dasar bersama ini akan dijadikan titik dasar penarikan garis batas sama jarak untuk membatasi laut teritorial Indonesia dan Australia di sebelah barat Laut Timor, sedangkan titik dasar di sebelah timur terletak di Pulau Meatiamiarang nomor TD-109, yang berfungsi sebagai titik dasar penarikan garis sama jarak untuk membatasi laut territorial, Indonesia dan Timor Leste di perbatasan sebelah timur antara Pulau Jaco dan Meatiamirang. Sebaliknya Timor Leste diperkirakan menetapkan 5 (lima) titik dasar yang terletak di pantai bagian selatan TimorTimur dan Pulau Jaco sebagai titik dasar penarikan garis pangkal untuk menentukan lebar laut teritorialnya di Laut Timor. Garis pangkal yang diterapkan oleh Timor Leste untuk menentukan lebar laut teritorial di Laut Timor adalah garis pangkal normal, sedangkan Indonesia menerapkan garis pangkal lurus kepulauan.

Garis pangkal lurus kepulauan yang diterapkan oleh Indonesia untuk menentukan lebar laut teritorial di Laut Timor, dilakukan dengan cara menghubungkan titik dasar Nomor TD. 110 di Pulau Ndana, dan titik dasar nomor 120 di Tanjung Tunfanu, Pulau Rote dengan Tanjung Batu Merah (TD.118), Tanjung Halkano (TD.117), Tanjung Batu Merah (TD. 116), Tanjung Wetoh (TD. 115) dan titik dasar bersama antara Indonesia dan Timor Leste di Mota Masin (TD.114), yang mengakibatkan perairan di sekitar pulaupulau tersebut menjadi perairan kepulauan
Indonesia. Berdasarkan garis pangkal yang diterapkan, selanjutnya Indonesia dan Timor Leste membatasi laut teritorial kedua negara dengan sama-sama menerapkan metode garis sama jarak (equidistance line). Batas terluar dari laut teritorial (outer limit) kedua negara di Laut Timor menjadi landas kontinen dan zona landas kontinen dan zona ekonomi eksklusif Indonesia.

\section{Simpulan}

Berdasarkan permasalahan dan analisis yang dilakukan maka dapat disimpulkan sebagai berikut:

1. Penetapan batas laut teritorial antara Indonesia dan Timor Leste di Selat Ombai dilakukan dengan cara:

a. Penetapan 3 (tiga) titik dasar bersama antara Indonesia dan Timor Leste, masing-masing di Pulau Timor dan Pulau Alor. Titik dasar bersama di Pulau Timor terletak di Noelbesi, Noelmeto dan Mota Biku, sedangkan titik dasar bersama di Pulau Alor terletak di Tanjung Losomo, Tanjung Seromu dan Tanjung Siberu;

b. Penerapan garis pangkal oleh Timor Leste adalah garis pangkal normal dan bukan garis pangkal lurus kepulauan maupun garis pangkal lurus dari ujung ke ujung karena Timor Leste tidak termasuk negara kepulauan dan tidak terdapat pulau atau teluk milik Timor Leste yang berada di depan pantai Oecusse, sedangkan Indonesia sebagai negara kepulauan dapat 
menerapkan garis pangkal kepulauan dan garis pangkal normal;

c. Penerapan metode garis batas oleh Indonesia dan Timor Leste adalah garis tengah (median line) dan garis sama jarak (equidistance line), yakni garis tengah diterapkan untuk memisahkan laut teritorial kedua negara di antara Pulau Pantar dan Alor dengan Oecusse di Pulau Timor, sedangkan garis sama jarak diterapkan untuk membatasi laut teritorial kedua negara yang saling berdampingan di Pulau Timor;

2. Penetapan batas laut teritorial antara Indonesia dan Timor Leste di Selat Wetar dilakukan dengan cara:

a. Penetapan 1 (satu) titik dasar bersama di Mota Biku yang merupakan titik batas darat antara kedua negara di sektor timur sebelah utara, sedangkan 3 (tiga) titik dasar sebagai dasar penarikan garis pangkal oleh Indonesia ditetapkan di sebelah selatan, tepatnya di Tutun Yen dan Tutun Eden Wetar Pulau Kisar dan Pulau Lirang. Sebaliknya Timor Leste akan menetapkan 7 (tujuh) titik dasar di pantai utara Timor-Timur dan 2 (dua) titik dasar di Pulau Atauro;

b. Penerapan garis pangkal oleh Timor Leste adalah garis pangkal lurus dari ujung ke ujung karena terdapat Pulau Atauro di depan pantai Timor Leste, yang memiliki jarak tempuh dari Dili $25 \mathrm{~km}$ atau 2,70 mil laut, sedangkan
Indonesia menerapkan garis pangkal lurus kepulauan dalam menetapkan batas laut teritorial dengan Timor Leste di Selat Wetar;

c. Penerapan metode garis batas oleh Indonesia dan Timor Leste adalah garis tengah untuk memisahkan laut teritorial kedua negara di antara Pulau Wetar dan Lirang dengan Timor Leste.

3. Penetapan batas laut teritorial antara Indonesia dan Timor Leste di Laut Timor dilakukan dengan cara:

a. Penetapan 1 (satu) titik dasar bersama di Mota Masin yang merupakan titik batas darat antara Indonesia dan Timor Leste di Sektor Timur Pulau Timor sebelah selatan, sedangkan pada batas sektor barat akan menjadi rumit dan kompleks karena keberadaan Pulau Jaco milik Timor Leste dan Pulau Leti, Moa dan Lacor milik Indonesia, sehingga kedua negara harus sepakat, apakah pulau-pulau kecil ini diberikan atau tidak diberikan bobot penuh untuk memiliki laut teritorial;

b. Penerapan garis pangkal oleh Timor Leste adalah garis pangkal normal sedangkan Indonesia menerapkan garis panglal lurus kepulauan;

c. Penerapan metode garis batas oleh Indonesia dan Timor Leste adalah garis sama jarak karena letak pantai dari kedua negara saling berdampingan. 


\section{DAFTAR PUSTAKA}

\section{Buku}

Araujo, de Maria, Rui \& Kay Rala Xanana

Gusmau. Timor Leste Maritime

Boundaries. Government of the

Democratic Republic of Timor Leste:

Maritime Boundaries Office, 2016.

Buntoro, Kresno. Nusantara dan Alur Laut

Kepulauan Indonesia (ALKI). Jakarta:

PT. Raja Grafindo Persada, 2017.

Oppenheim. International Law, A Treatise.

Vol.I London-New York-Toronto:

Longmans, Green And Co, 1948.

Shaw, N, Malcolm. International Law.

Camridge: Camridge University Press, 2008.

Soekanto, Soerjono dan Sri Mamuji. Penelitian

Hukum Normatif, Suatu Tinjauan

Singkat. Jakarta: Raja Grafindo, 2003.

Sitohang, Japanton, et al. Masalah Perbatasan

Wilayah Laut Indonesia di Laut Arafura

dan Laut Timor. Jakarta: Lembaga Ilmu

Pengetahuan Indonesia, 2009.

Tanaka, Yoshifuna. Predictability and Flexibility in the Law of Maritime

Delimitation, North America (USA and Canada): Oxford and Portland Oregon, 2006.

\section{Jurnal}

Abidin, Z. Hasanuddin, et al. "Status dan Permasalahan Teknis Dari Delimitasi Batas Laut Indonesia-Timor Leste".
Jurnal Suveying dan Geodesi, Vol. XIII

No. 1, (Januari 2003).

Afriansyah, Arie, “Kewenangan Negara Pantai

Dalam Mengelola Wilayah Laut", Jurnal Hukum dan Pembangunan, Vol. 45, No. 4, (Oktober-Desember 2015).

Agoes, R, Etty, "Praktek Negara-Negara Atas Konsepsi Negara Kepulauan", Jurnal Hukum Internasional Fakultas Hukum Universitas Indonesia, Vol. 1, No. 3, (April 2004).

Anggita, Mutti, "Kesepakatan Batas Darat RI-Timor Leste, Sebuah Kajian Diplomasi Perbatasan RI', Jurnal Penelitian Politik, Vol. 11 No. 1, (Juni 2014).

Armandha, Tyar, Semmy, "Posisi Bebas Aktif Indonesia Dalam Rivalitas Tiongkok dan Amerika di Asia Tenggara Terkait Pengadaan Alutsista", Jurnal Pertahanan, Vol. 6, No. 3, (Desember 2016).

Monteiro, Sequito, "Yurisdiksi Negara Pantai Di Wilayah Delimitasi Maritim Zona Ekonomi Eksklusif Yang Belum Ditetapkan Berdasarkan Ketentuan Hukum Laut Internasional", Jurnal Komunikasi Hukum (JKH) Universitas Pendidikan Ganesha, Vol. 6, No. 1 (Februari 2020).

Potemra, T, James, et., al., "Interaction Between the Indonesia and the Indian Ocean in 
Observations and Numerical Models", Journal of Physical Oceanography, Vol. 32, (Juni 2002).

Prakoso, Yudho, Lukman, et., al., "Sea Defense Strategy and Urgency of Forming Maritime Command Centre" Jurnal Pertahanan, Vol. 6, No. 2, (2020).

Sudjatmiko dan Rusdi Ridwan. "Batas-Batas Maritim antara Republik Indonesia dengan Negara Tetangga”. Jurnal Hukum Internasional, Edisi Khusus, Jakarta: Lembaga Pengkajian Hukum Internasional Fakultas Hukum Universitas Indonesia (Desember 2004).

Suharyo, "Penegakan Keamanan Maritim Dalam NKRI dan Problematikanya" Jurnal Penelitian Hukum De Jure, Vol. 19, No. 3, (September 2019).

\section{Makalah}

Arsana, Andi, Made, I, Chris Rizos \& Clive Schofield. The Application of GIS In Matime Boundary Delimitation, A Case Study on the Indonesia-East Timor Maritime Boundary Delimitation.

Australia: University of Wollongong Research Online, 2006.

Devenport, Tara. Southeast Asian Approaches To Maritime Delimitation, Paper Presented $3^{\text {rd }}$ NUS ASIANSIL Young Scholars Workshop, National University of Singapore: Research Associate, Centre for International Law, 23-24 Februari 2012.

\section{Website}

Case Concerning Maritime Delimitation And Territorial Question Qatar vs Bahrain, 16 Maret 2001, www.icj-cij.org.case, diakses pada tanggal 20 Agustus 2017.

ITLOS Judgment, Dispute Concerning Delimitation of the Maritime Boundary Between Bangladesh and Myanmar in the Bay of Bengal, Bangladesh VS Myanmar No, 16, 2012 https://www. itlos.org/cases/list-of-cases/case-no16 " diakses pada tanggal 17 September 2017.

Mohd Hazmi bin Mohd Rusli, Maritime Highways of Southeast Asia, Alternative Straits?, (Nanyang: S. Rajaratnam School of International Studies, A Graduate School of Nanyang Technological University, 2012, No.024/2012), www.rsis.edu.sg, diakses pada tanggal 15 Maret 2017.

Laut Timor, Wikipedia, https://id.wikipedia. org, diakses pada tanggal 4 Maret 2020.

Pulau Batek, www.ppk-kp3k.kkp.go.id, diakses pada tanggal 07 April 2017.

\section{Perjanjian Internasional dan Peraturan Perundang-Undangan}

The 1982 United Nation Convention on the Law of the Sea (UNCLOS).

Peraturan Pemerintah Republik Indonesia Nomor: 37 Tahun 2008 Tentang Perubahan Atas Peraturan Pemerintah Nomor: 38 Tahun 2002 Tentang Daftar Koordinat Geografis Titik-Titik Garis Pangkal Kepulauan Indonesia. 